\title{
Dentális implantátumok eltávolításának retrospektív értékelése
}

\author{
IVÁNYI DÓRA, DR. KIVOVICS PÉTER
}

\begin{abstract}
A dentális implantátumok túlélési aránya 95,0-100,0\% közé tehető. Az implantációs kezelések elterjedtsége és nagyszámú alkalmazása miatt fontosnak tartjuk a reménytelen prognózisú implantátumok ellátásának és kialakulásának vizsgálatát. Vizsgálatunk célja a Fogászati és Szájsebészeti Oktató Intézet elmúlt négy évében történt implantátum-eltávolítások összehasonlító értékelése. A vizsgálathoz szükséges adatokat a Fogászati és Szájsebészeti Oktató Intézetben fellelhető röntgenképek, kórlapok, illetve a FOGÁSZ nevű betegkezelő program segítségével gyűjtöttük. Adatainkat Excel táblázatban értékeltük. A vizsgált páciensek 36,7\%-ánál fordult elő implantátumon és természetes fogazaton egyszerre elhorgonyzott fix fogpótlás. Az eltávolított implantátumok $77,6 \%$-ánál fordult elő periimplantitis. A természetes fogazattal rendelkezők 50,0\%-ánál volt jelen horizontális csontfelszívódás, míg 12,5\%-uknál vertikális csontdefektus volt megfigyelhető. A nem megfelelő biomechanikai körülmények miatt lehetőleg kerüljük a fogon és implantátumon egyszerre elhorgonyzott fix fogpótlás tervezését. A periimplantalis gyulladás az egyik legfontosabb faktor az implantátumok elvesztésénél, ezért megelőzése kiemelt fontosságú. A sikeres implantáció érdekében parodontitisben szenvedő betegeinket az implantáció előtt kezeljük ki a fogágygyulladásukból.
\end{abstract}

Kulcsszó: Dentális implantátum, Implantációs szövődmények, Implantátum eltávolítás, Periimplantitis

\section{Bevezetés}

Míg az implantológia kezdeti időszakában az implantátumokat csupán a hagyományos fogpótlások kiegészítéseként használták, manapság meghatározó része a mindennapi fogorvosi tevékenységnek. Az implantációk sikerességét különböző szempontok alapján értékelhetjük, ezek az aspektusok igen sokat változtak az elmúlt három évtizedben [1]. Az implantátumok értékelésénél többek közt figyelembe kell vennünk az osseointegratio minőségét, az implantátumokon elhorgonyzott és megtámasztott fogpótlások funkcióképességét és esztétikáját, és a periimplantalis szövetek gyulladásmentességét [1-5]. A nemzetközi irodalomban az implantátumok hosszú távú sikeressége igen széles skálán, 74,5$100,0 \%$ közt mozog, mivel az egyes kutatások nem egységes kritériumrendszert használnak vizsgálatuk során [6]. Sok esetben a sikertelennek számító implantátumoknál létezik megfelelő kezelési metódus, azonban a reménytelen prognózisú implantátumoknál eltávolításra kerül sor. Egyértelmü tehát, hogy az implantátumok sikerességi és túlélési aránya nagy mértékben eltérhet. Ezt az eltérést megfigyelhetjük például Galucci és mtsai. munkájában, ahol a vizsgált populációban az implantációk sikerességi aránya $86,7 \%$ volt, míg a túlélési arány 95,5\% [7].

Az eltávolítás indikációit két fő csoportra bonthatjuk idő szerint, attól függően, hogy az implantátum osseointegratiója elérte-e a maximumát, avagy nem. Abban az esetben, ha az implantátum eltávolítása az implantátum maximális osseointegratiója előtt lesz javallott, korai indikációról beszélünk, míg késői indikációnak nevezzük, ha a teljes csontosodás után lesz ajánlott az implantátum kivétele.

Korai indikációk közé sorolhatók az implantátum behelyezésével történő szöveti sérülések. Előfordulhat az alsó állcsonton a nervus alveolaris inferior sérülése, amennyiben az implantátum eléri a canalis mandibulaet vagy beroppantja annak falát. Az idegsérülés mértékétől függően különböző panaszokról számolhatnak be a páciensek, de a nervus alveolaris inferior sérülésekor leggyakoribb tünet az áll zsibbadása [8]. Sérülhetnek a canalis mandibulae képletein kívül az implantátum környezetében lévő fogak is. Ezekben az esetekben a terápia sokrétű, előfordulhat, hogy a sérült fogat gyökérkezeljük vagy eltávolítjuk, de javasolt lehet a károsodást okozó implantátum eltávolítása is [9]. Nem megfelelő tervezés, illetve kivitelezés esetén előfordulhat, hogy az implantátum malpositióba kerül beültetésre, ami miatt szintúgy eltávolításra kerülhet az implantátum [10, 11]. Megfelelő képalkotói eljárások, mint például a CBCT, elősegítheti az implantátum tervezett helyére történő beültetését. Ajánlott lehet az implantátum kivétele azokban az esetekben is, mikor nem megfelelő a primer stabilitás. Túl nagy primer stabilitás esetében az implantátum körül később csontfelszívódás jöhet létre, míg túl alacsony primer stabilitásnál az implantátum nagyobb amplitúdójú mikromozgásai gá- 


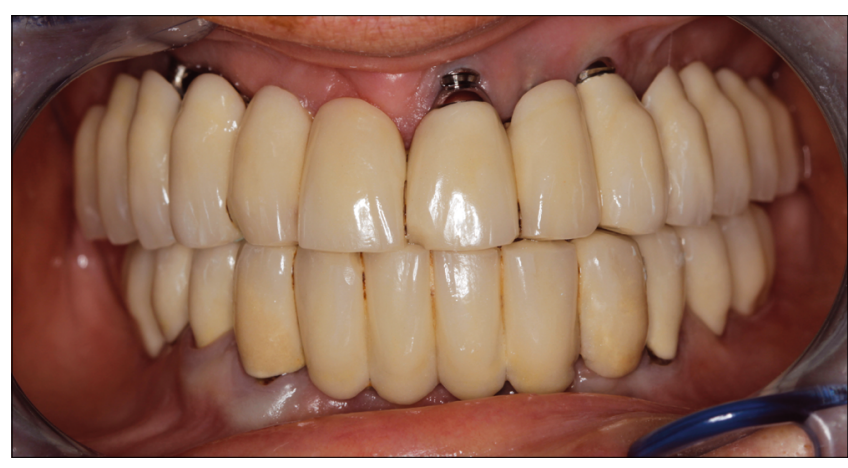

1. ábra: Periimplantitis.

Az implantátum körüli lágy és a kemény szövetek gyulladása miatt a páciensnek több csavarmenettel ellátott implantátumfelszíne is szabaddá vált.

tolják az osseointegratio folyamatát [12]. Fontos megemlítenünk a korai indikációk közt az osseointegratio kifejlődése előtt létrejövő gyulladásos folyamatokat. Előidézhet gyulladásos reakciót az implantátum behelyezésénél túl magas fordulatszámmal történő csontfúrás, nem megfelelő sebészi hútés és a nem megfelelően kontrollált sebgyógyulás [13].

A késői indikációkat három alcsoportra bonthatjuk. Biológiai indikációk közé sorolhatjuk a periimplantitist (1. ábra). A periimplantitis az implantátum körüli lágyés keményszövetek gyulladásos reakcióit jelöli [14]. A kórkép igen gyakorinak tekinthető, a beültetett implantátumok 10\%-ánál és az implantátumot kapott páciensek 20\%-ánál fordul elő periimplantitis [15]. Hajlamosítható tényező lehet a nem megfelelő szájhigiénia, a dohányzás, a rosszul tisztítható vagy túlterhelt fogpótlások, az implantátum körüli feszes íny hiánya, illetve különböző szisztémás betegségek jelenléte [16]. A periimplantitis kezelhető különféle konzervatív eljárásokkal, sebészi terápiával, de bizonyos esetekben az implantátum eltávolítása is ajánlott lehet [17]. Mechanikai indikációk közé tartozik az implantátum felépítményének vagy magának az implantátumnak a sérülés vagy törése. Ezek az állapotok leggyakrabban az implantátum túlterhelése miatt jönnek létre [18]. Külön csoportra bontottuk az általános egészségi állapottal összefüggő indikációkat. Ajánlott lehet az eltávolítás tumor közeli implantátumnál, ha az implantátum befolyásolja a daganat gyógyulását. Indikált lehet az eltávolítás irradiatiós terápiánál, ha az implantátum körüli szöveteket éri a besugárzás [19, 20].

A téma aktualitása miatt a Fogászati és Szájsebészeti Oktató Intézet implantátum-eltávolításokkal foglalkozó munkacsoportja célul tǔzte ki jelen témakör tanulmányozását. Vizsgálatunk célja a Fogászati és Szájsebészeti Oktató Intézet elmúlt négy évében történő implantátum-eltávolítások összehasonlító értékelése, alapadatok nyerése a témával kapcsolatban. Kutatásunk kiterjedt a vizsgált betegpopuláció életkori és nemi megoszlásának, az eltávolított implantátumok állcsontokon belüli elhelyezkedésének, az eltávolított im- plantátumok beültetése és kivétele között eltelt időtartamának, az eltávolított implantátumokon elhorgonyzott fogpótlások típusainak, illetve az eltávolított implantátumok esetében előforduló szövődmények értékelésére.

\section{Anyag és módszer}

A Fogászati és Szájsebészeti Oktató Intézet elmúlt négy évében 30 páciens (19 nő és 11 férfi) $58 \mathrm{db}$ implantátuma került eltávolításra. Az eltávolított implantátumok 87,5\%-a az Intézeten kívül került beültetésre. A vizsgálathoz szükséges adatokat a Fogászati és Szájsebészeti Oktató Intézetben fellelhető röntgenképek, kórlapok, illetve a FOGÁSZ elnevezésű betegkezelő program segítségével gyüjtöttük. Adatainkat Excel táblázatban értékeltük.

\section{Eredmények}

\section{Életkor szerinti megoszlás}

Betegcsoportunk átlagos életkora 64,3 év volt ( $\pm 8,8$ év). Nem mutatkozott jelentős eltérés a nők és a férfiak átlagos életkora között. A nők átlagos életkora 62,5 év ( $\pm 5,7$ év), míg a férfiaké 66,0 év ( $\pm 12,6$ év) volt. A vizsgált betegpopuláció $96,7 \%$-a az implantátum kivételekor már betöltötte 50 . életévét. A betegek 3,3\%-a 31-40 év, 26,7\%-a 51-60 év, 50,0\%-a 61-70 év és 20,0\%-a 71-80 év közti korcsoportba volt sorolható.

\section{Implantátumok állcsontokon belüli elhelyezkedése}

Elemeztük pácienseink beültetett és eltávolított implantátumainak állcsontokon belüli megoszlását, figyelembe véve a lateralitást. Az implantátum-eltávolításon átesett betegpopulációnak összesen $108 \mathrm{db}$ implantátum került beültetésre, páciensenként átlagosan 3,4 db $( \pm 3,7 \mathrm{db})$. A beültetett implantátumok állcsontokon belüli elhelyezkedésének százalékos megoszlása a 2. ábrán látható. $A$ betegminta beültetett implantátumainak 53,7\%-a került eltávolításra, ez összesen $58 \mathrm{db}$ implantátumot tett ki. Páciensenként átlagosan 1,9 db ( $\pm 1,9 \mathrm{db})$ implantátum került kivételre. Az eltávolított implantátumok állcsontokon belüli százalékos megoszlása a 3. ábrán látható. Az eltávolított implantátumok 55,2\%-a a maxillában volt megtalálható.

\section{Az implantátumok túlélésének ideje}

25 betegnél állt rendelkezésünkre adat arra nézve, menynyi idő telt el az eltávolításra kerülő implantátumok beültetése és kivétele között. A vizsgált betegpopulációnak 20,0\%-a az osseointegratio kialakulása előtt, az első fél évben vesztette el implantátumait. Ennek megoszlása: 8,0\%-nak a mútét után azonnal, 12,0\%-nak 0,5 év elteltével kellett eltávolítani implantátumait. A betegminta 8,0\%-ának 1 év, 4,0\%-ának 3 év, 4,0\%-ának 4 év, 12,0\%-nak 5 év, 16,0\%-ának 6 év, 4,0\%-ának 7 év, 4,0\%-ának 9 év, 16,0\%-ának 10 év, 8,0\%-ának 11 év 


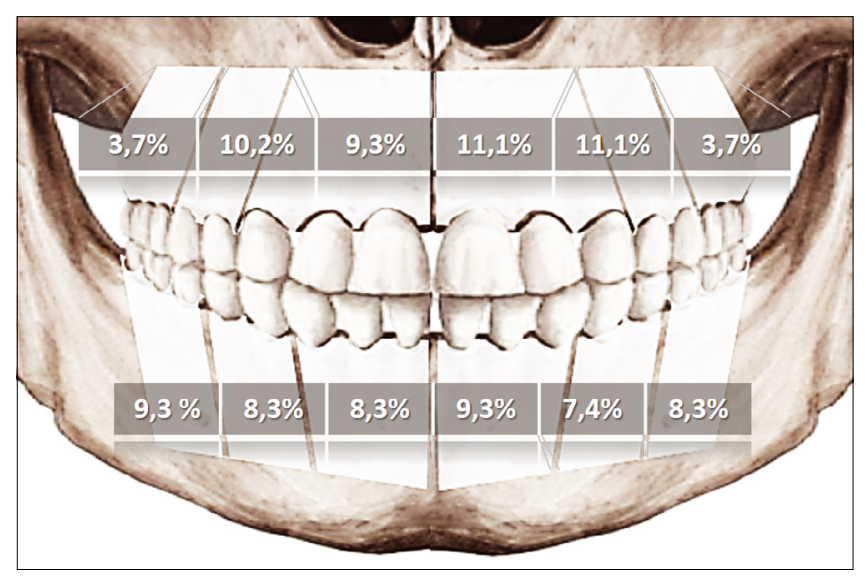

2. ábra: A beültetett implantátumok állcsontokon belüli százalékos megoszlása

körül, és 4,0\%-ának 11,5 év után került eltávolításra az implantátuma. A pácienscsoport átlagosan 5,8 $( \pm 4,3$ év $)$ évig viselte beültetett implantátumait (4. ábra).

\section{Az eltávolított implantátumokon elhorgonyzott fogpótlások típusai}

Vizsgálatunk kiterjedt az eltávolított implantátumokon elhorgonyzott és megtámasztott fogpótlások típusainak megoszlására is. A páciensek 36,7\%-ánál fordult elő implantátumon és természetes fogazaton egyszerre elhorgonyzott és megtámasztott fix fogpótlás. 33,3\%-uk implantátumon elhorgonyzott és megtámasztott fix fogpótlást, 20,0\%-uk implantátumon elhorgonyzott és/vagy megtámasztott fedóprotézist, míg 10,0\%-uk implantátum pillérü szóló koronát viselt (5. ábra).

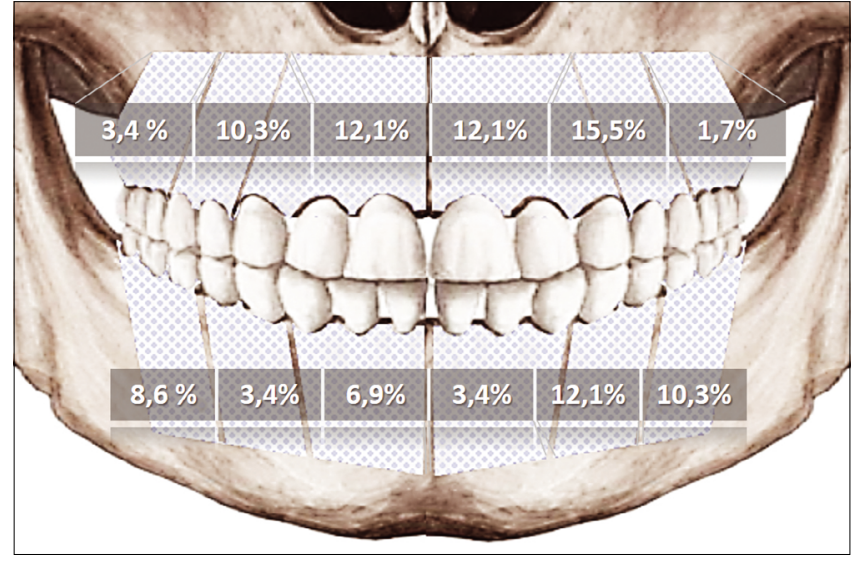

3. ábra: Az eltávolított implantátumok állcsontokon belüli százalékos megoszlása

\section{Az eltávolított implantátumok esetében előforduló szövődmények}

Az eltávolított implantátumok $77,6 \%$-ánál fordult elő periimplantitis. A vizsgált betegcsoport $26,7 \%$-a teljes foghiánnyal rendelkezett. A természetes fogazattal rendelkezők $50,0 \%$-ánál volt jelen horizontális csontfelszívódás, míg 12,5\%-uknál vertikális csontdefektus volt megfigyelhető fogaik körül. Az esetek 12,1\%-ánál osseointegratio előtti gyulladásos folyamatot regisztráltunk. Csupán 2 esetben került malpositio miatt eltávolításra implantátum, ami az összes eltávolított implantátum 3,4\%-át teszi ki. A 58 db eltávolított implantátum közül 2 esetben volt mechanikai indikációja az eltávolításnak (6. ábra).

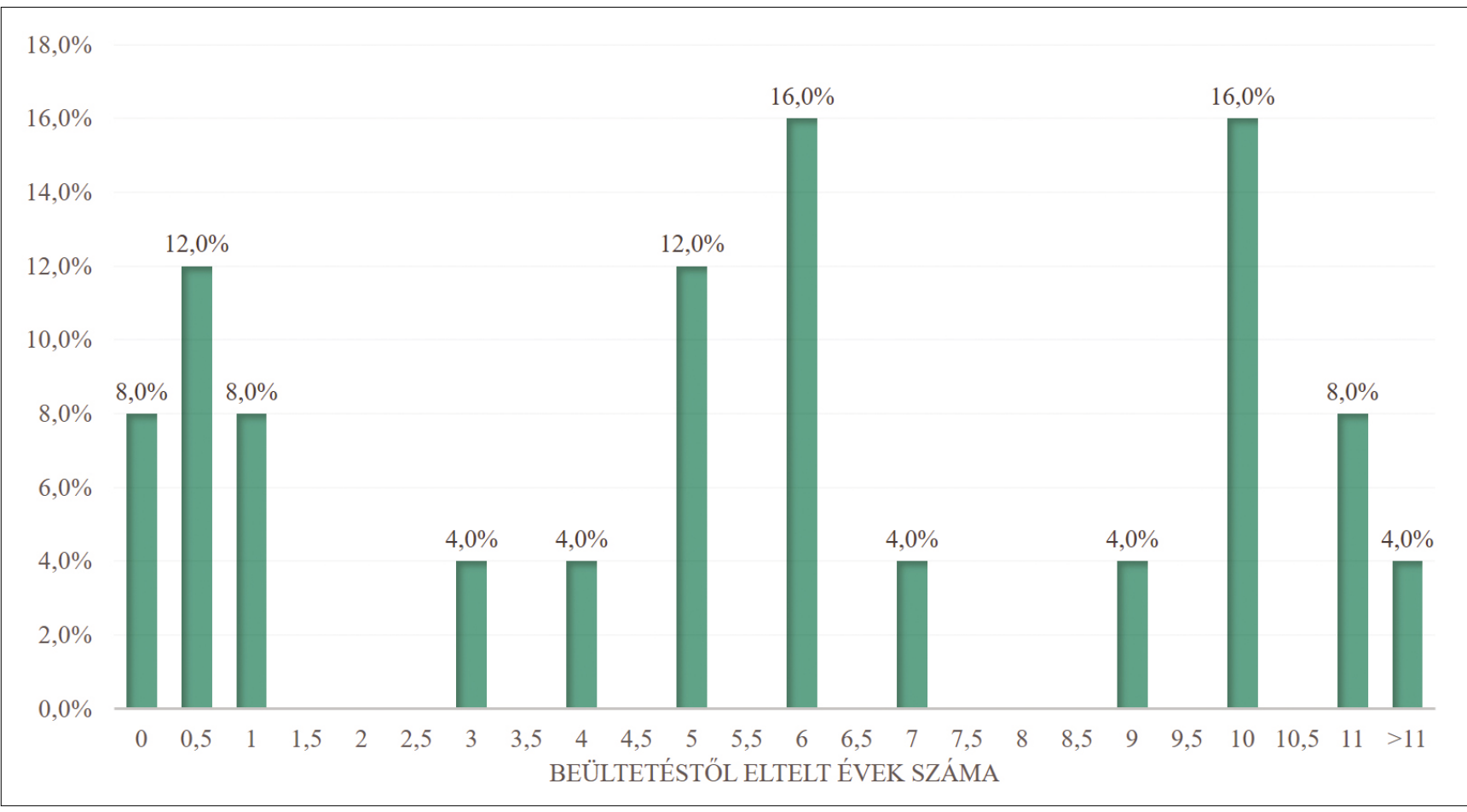

4. ábra: Az eltávolított implantátumok százalékos eloszlása a beültetés és kivétel között eltelt idő függvényében 


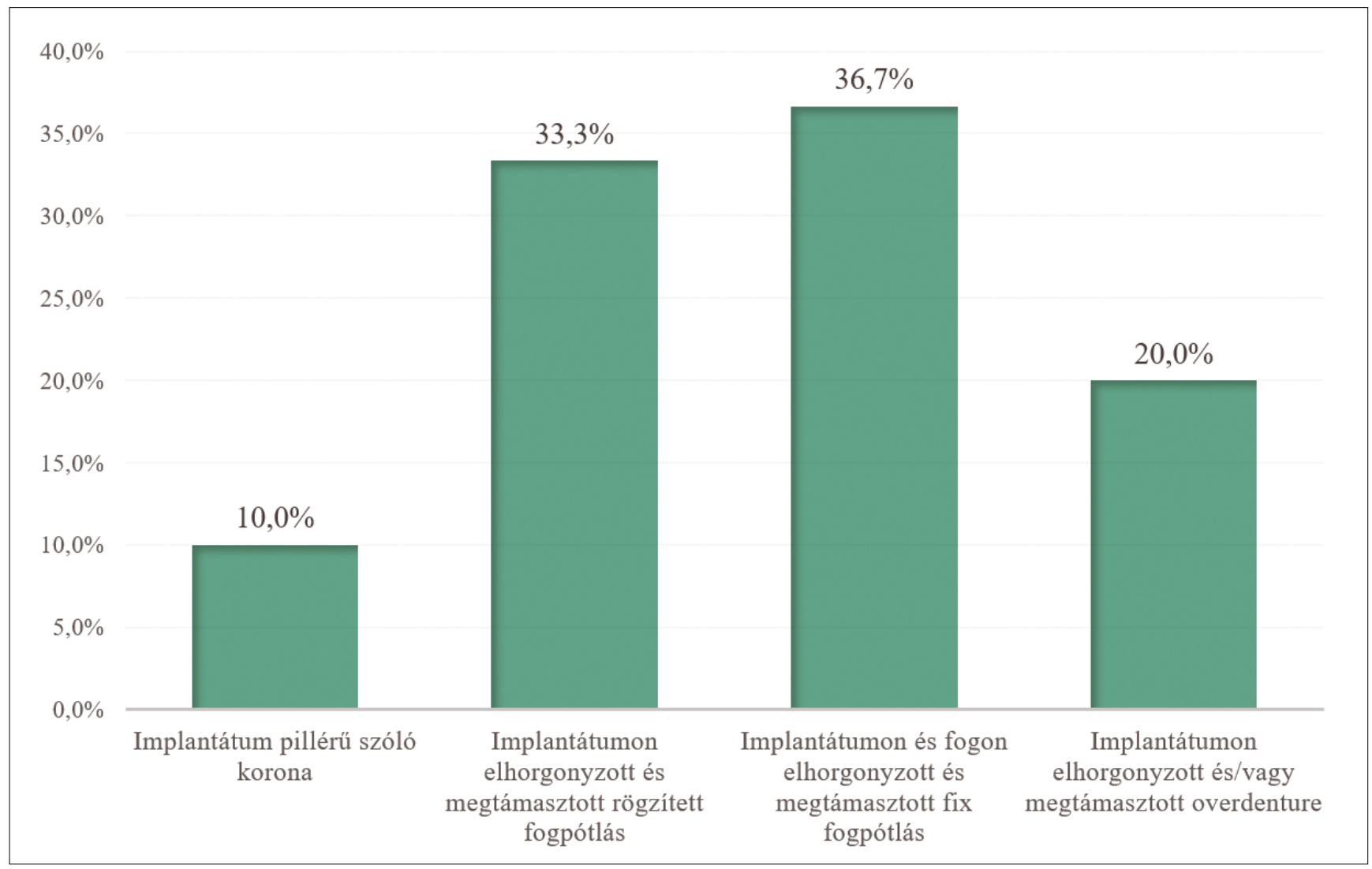

5. ábra: A betegcsoport által viselt fogpótlások típusainak százalékos megoszlása

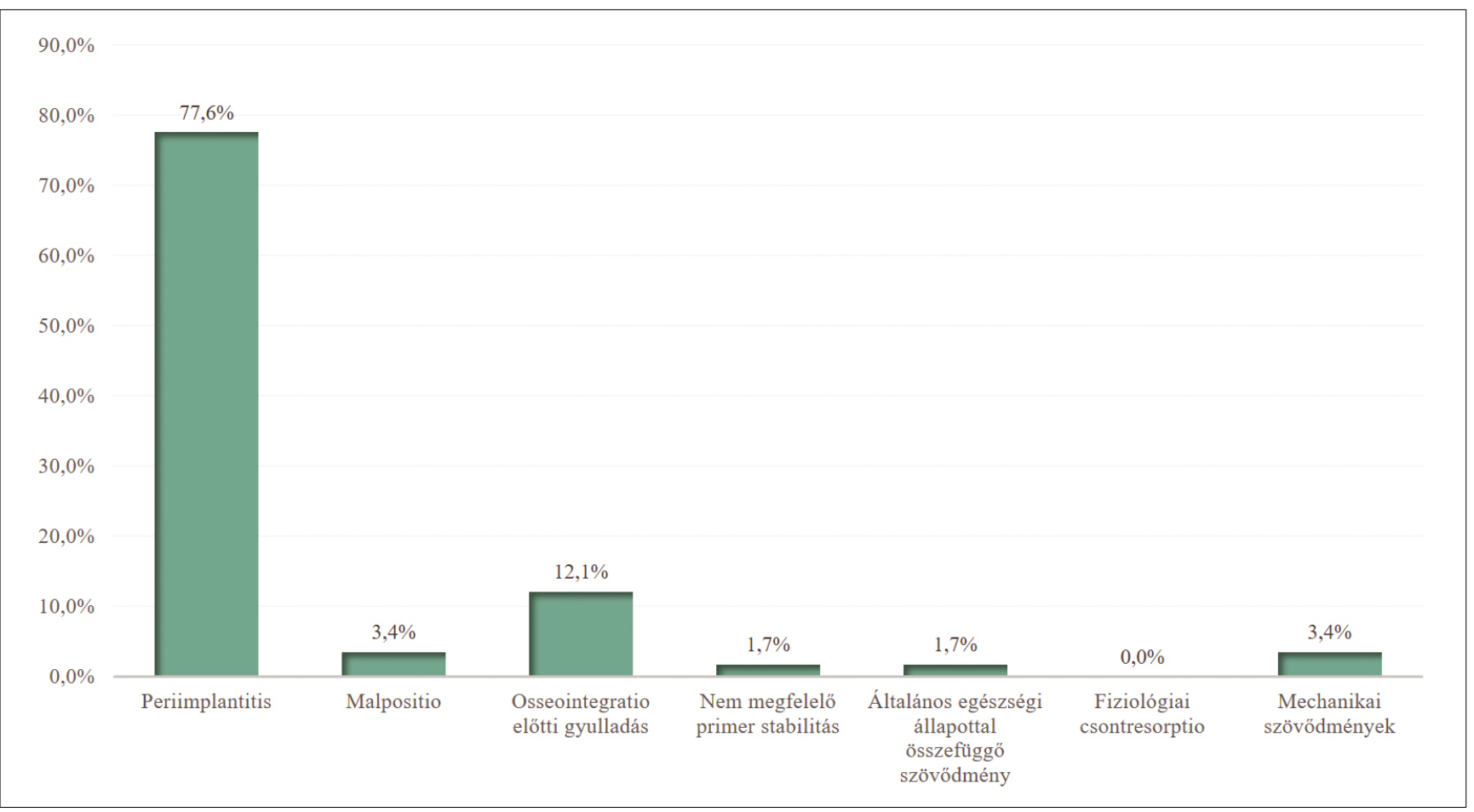

6. ábra: Az eltávolított implantátumok esetében előforduló szövődmények előfordulása 


\section{Megbeszélés}

50 év felett megnő mind a cardiovascularis megbetegedések, a kettes típusú cukorbetegség és a daganatos megbetegedések prevalenciája is [21, 22, 23]. A fent említett kórképek, illetve ezek terápiái etiológiai tényezőként szerepelhetnek az implantátumok elvesztésével kapcsolatban. Egy 2008-ban végzett felmérés szerint Magyarországon 45 év felett jelentősen emelkedik a foghiányok száma [24]. A foghiányok előfordulásával párhuzamosan növekszik a fogpótlások száma, köztük az implantáción elhorgonyzott fogpótlásoké is [25]. Ezek alapján levonhatjuk azt a következtetést, hogy az idősebb populációban a beültetett implantátumok nagyobb gyakorisága is növelheti az 50 év felettieknél eltávolított implantátumok előfordulását. Véleményünk szerint az ötven év felettiek $96,7 \%$-os előfordulását a vizsgált populációban nem magyarázhatjuk csupán az idősebb korosztályt érintő egészségi problémákkal.

Az eltávolított implantátumok elhelyezkedésével kapcsolatosan megfigyelhetjük, hogy a beültetett és az eltávolított implantátumok állcsontokon belüli százalékos megoszlása hasonlóságot mutat a maxilla és a mandibula egyes régióiban, eltérés a maxilla front és premolaris régiójában jelentkezik. Az eltávolított implantátumok megoszlásánál jelentős különbséget láthatunk a jobb és a bal oldal között, mind a maxilla premolaris, mind a mandibula front, premolaris és molaris régióiban. A fent említett eltérések okainak magyarázata eddig még nem tisztázott kutatásunkban, ehhez további standardizált kutatások szükségesek. A maxillában és a mandibulában körülbelül egyenlő arányban fordultak elő az eltávolítások. Esetünkben nem tudunk arra következtetni, hogy a maxilla és a mandibula vérellátási és szerkezeti különbözőségei befolyásolnák-e az implantátumok túlélését.

Az eltávolított implantátumok kihordási idejével kapcsolatban megfigyelhetjük, hogy három maximumot találunk az idő-tengelyen. Az első tüske a beültetéstől számított első évben található. Ezekben az esetekben az implantátumok korai indikációk miatt lettek eltávolítva. A második tüskét 5-6 év körül figyelhetjük meg,

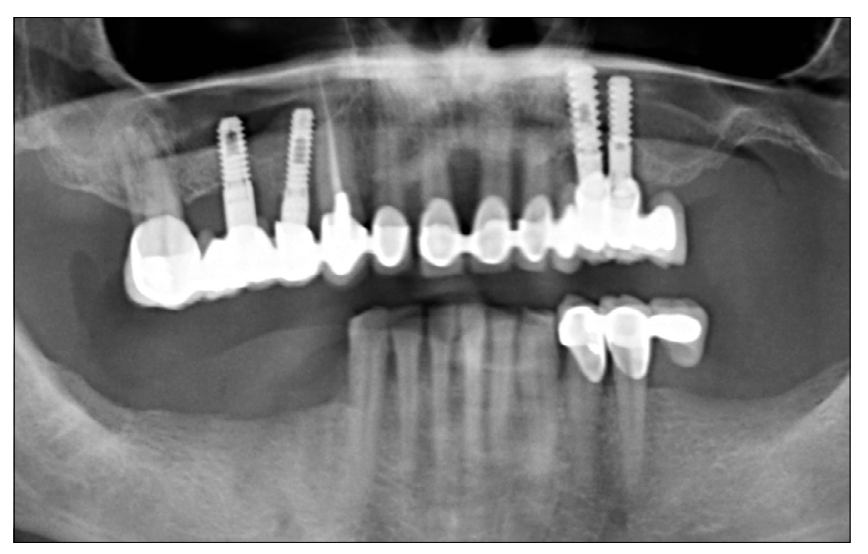

7. ábra: Természetes fogakon és implantátumon egyszerre elhorgonyzott és megtámasztott fogpótlás röntgenképe ezekben az esetekben gyakori volt a nehezen tisztítható fogpótlás, illetve egy páciens kivételével mindenki természetes fogon és implantátumon elhorgonyzott és megtámasztott fix fogpótlással rendelkezett. Feltételezzük, hogy a fogpótlás nem megfelelő tervezése és kivitelezése miatt kialakuló periimplantitis növelte meg ebben a szakaszban gyakrabban előforduló implantátum-eltávolítások számát. Az utolsó tüske az idő-tengelyen 10 év körül jelentkezik. Ezeknél az eseteknél szinte minden típusú fogpótlás előfordult. Valószínúsíthető, hogy a periimplantitis kialakulásában szerepet játszó alacsony rizikójú etiológiai tényezők additív hatásai 10 év alatt érhetnek el olyan mértékű gyulladást és csontfelszívódást, ami az implantátum eltávolítását indikálja.

Az implantátum-eltávolításon átesett betegpopulációnál a leggyakoribb fogpótlástípus az implantátumon és természetes fogakon egyszerre elhorgonyzott és megtámasztott fix fogpótlás volt (7. ábra). A fogpótlás tervezésekor figyelembe kell vennünk a természetes fogazat, az implantátumok és a rajtuk elhorgonyzott és megtámasztott fogpótlások biomechanikai tulajdonságait. A természetes fogazat rugalmas kapcsolatot létesít a csontszövettel a parodontális ligamentumok által, így a fogakhoz kapcsolt fix pótlások mikromozgással rendelkezhetnek. Az implantátum merev, ankilotikus kapcsolattal rögzül a csontszövethez, hiszen nincsenek jelen parodontális ligamentumok az implantátum és a csont között. Az implantátumon elhorgonyzott és megtámasztott fix pótlások esetében nem, vagy csak igen kismértékű mikromozgás tapasztalható [26]. Ha a két különböző típusú kapcsolódási formát egy rögzített fogpótlással, tehát egy merev kapcsolattal összekötjük, a természetes fogaknál létrejövő mikromozgások áttevődnek az implantátumokra is. A mikromozgásokból származó erők idővel meggyengíthetik az implantátum-csont kapcsolatot, segítve a kórokozók bejutását és megtapadását az implantátum körül, ezzel elősegítve a periimplantitis kialakulását $[27,28]$. A fent említett okok miatt munkacsoportunk a fogon és implantátumon egyszerre elhorgonyzott és megtámasztott fix fogpótlás tervezését nem ajánlja. A második leggyakoribb fogpótlástípus az implantátumon elhorgonyzott és megtámasztott híd volt. Sok esetben volt megfigyelhető a balkonos, nehezen tisztítható pótlások jelenléte. Ezekben az esetekben feltételezhető a dentális plakk fokozott felhalmozódása, ami elősegíti a periimplantalis gyulladás kialakulását, ezzel hozzájárulva az implantátum elvesztéséhez [14, 29]. Az implantátumon elhorgonyzott hidak esetében törekedjünk megfelelően tisztítható fogpótlás készítésére, illetve a páciens megfelelő egyéni szájhigiéniás szokásainak kialakítására.

Az eltávolított implantátumok több mint háromnegyedénél volt jelen periimplantitis. A magas előfordulási arány mutatja, hogy a periimplantalis gyulladás az egyik legfontosabb faktor az implantátumok elvesztésénél. Bizonyos etiológiai tényezők jelenléte elősegíti a kórkép kialakulását, mint például a nem megfelelő szájhigiénia, a dohányzás, az implantátum nem megfelelő 
terhelése, a feszes gingiva hiánya, különböző szisztémás betegségek és a nem megfelelően tervezett vagy kivitelezett fogpótlások készítése (8. ábra) [16]. Minden esetben igyekezzünk minimalizálni a kórkép kialakulását elősegítő faktorok jelenlétét. A páciens megfelelő szájhigiéniája alapvető fontosságú a gyulladás prevenciójában, de csökkenthetjük a kialakulás esélyét rendszeres kontrollvizsgálatok elrendelésével is.

Elősegítheti a periimplantitis kialakulását a parodontitis is. A parodontitisben szenvedő betegek körében hatszor nagyobb a periimplantitis incidenciája, aminek oka, hogy a fogágyban gyulladást okozó baktériumok az implantátum felszínén is képesek megtapadni, és ott periimplantitist hoznak létre [30, 31]. A Fogászati és Szájsebészeti Oktató Intézet elmúlt négy évében foggal rendelkező és implantátum-eltávolításon átesett betegek 50,0\%-ánál jelen levő horizontális csontpusztulás megerősíti azt a feltevést, miszerint összefüggés van a parodontalis status és az implantátumok túlélése között. A fogágygyulladás kikezelésével csökkenthetjük annak esélyét, hogy a parodontalis anaerob flóra megtapadjon az implantátum körül és gyulladást okozzon.

12,1\%-a az eltávolított implantátumoknak az osseointegratiót megelőző gyulladásos reakciók következtében kerültek eltávolításra. Ezekben az esetekben befolyásolhatta a gyógyulási folyamatot a kevéssé atraumatikus sebészi ellátás, a sebek nehezebb tisztíthatósága, az implantátum gyógyulásának zavartsága, a nem megfelelő sebellátás miatt kialakult dehistentia és a nem kielégítő szájhigiénia [32]. Az implantátum csontosodása szempontjából esszenciális faktor a gyulladásmentes gyógyulás. Az általunk legjobban kontrollálható sebellátási technikát válasszuk pácienseinknek, hiszen ezzel csökkenthetjük legjobban a gyulladásos folyamatok progresszióját.

Köszönetnyilvánítás: A szerzők köszönik dr. Czinkóczky Bélának, dr. Kivovics Mártonnak és a Fogászati és Szájsebészeti Oktató Intézet Szájsebészeti osztályának a kutatáshoz való hozzájárulásukat.

Anyagi támogatás: A kutatás az Emberi Erőforrások Minisztériuma ÚNKP-17-2 kódszámú Új Nemzeti Kiválóság Programjának támogatásával készült.

Szerzői munkamegosztás:

K. P.: hipotézisek, koncepció kidolgozása, Új Nemzeti Kiválóság Program-pályázat megírása, kézirat korrekciója, szakmai lektorálás

I. D.: koncepció kidolgozása, Új Nemzeti Kiválóság Program-pályázat megírása, a vizsgálat lefolytatása, adatok elemzése, kézirat megszövegezése, ábrák szerkesztése

A cikk végleges változatát valamennyi szerző elolvasta és jóváhagyta.

A szerzőknek nincsenek érdekeltségeik.

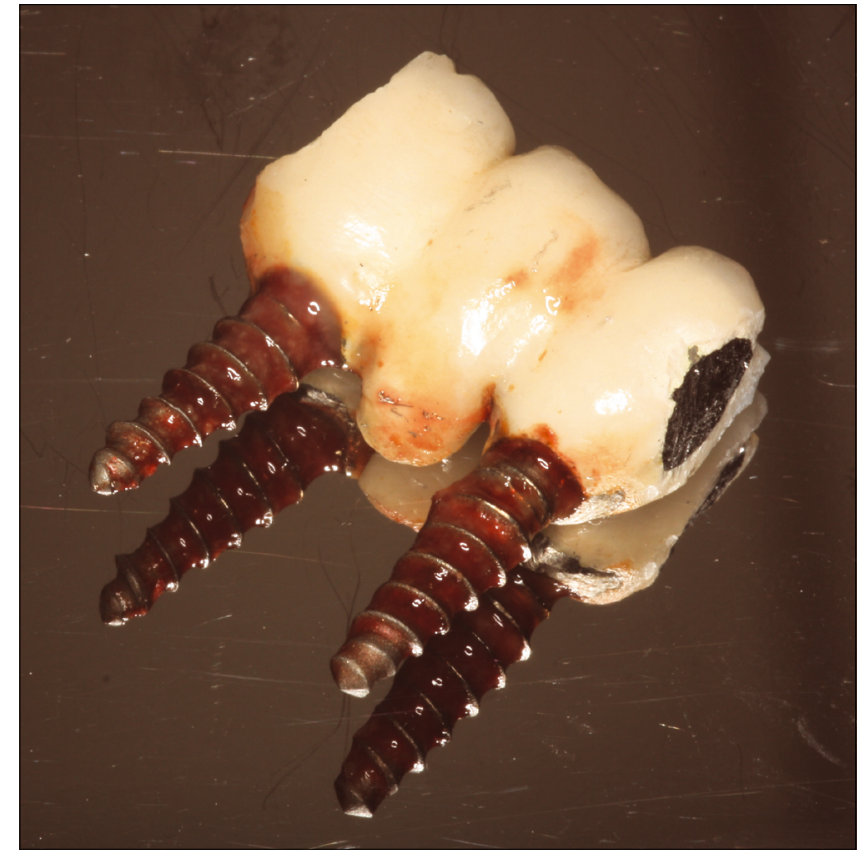

8. ábra: Periimplantitises környezetből, fogpótlással együtt eltávolított implantátumok

\section{Irodalom}

1. Albrektsson t, Zarb G, Worthington P, Eriksson AR: The longterm efficacy of currently used dental implants: a review and proposed criteria of success. Int J Oral Maxillofac Implants. 1986; 1: 11-25.

2. Albrektsson T, ZarB GA: Determinants of correct clinical reporting. Int J Prosthodont. 1998; 11: 517-521.

3. Sмith DE, ZARB GA: Criteria for success of osseointegrated endosseous implants. J Prosthet Dent. 1989; 62: 567-572.

4. Buser D, Weber HP, LANG NP: Tissue integration of non-submerged implants. 1-year results of a prospective study with 100 ITI hollow-cylinder and hollow-screw implants. Clin Oral Implants Res. 1990; 1: 33-40.

5. MISCH CE ET AL: Implant success, survival, and failure: the International Congress of Oral Implantologists (ICOI) Pisa Consensus Conference. Implant Dent. 2008; 17: 5-15.

6. Papaspyridakos P, Chen CJ, Singh M, Weber HP, Gallucci GO: Success Criteria in Implant Dentistry: A Systematic Review. J Dent Res. 2012; 91: 242.

7. Gallucci GO, Doughtie CB, Hwang JW, Fiorellini JP, Weber HP: FIVE-year results of fixed implant-supported rehabilitations with distal cantilevers for the edentulous mandible. Clin Oral Implants Res. 2009; 20: 601-607.

8. Alhassani AA, AlGhamdi AS: Inferior Alveolar Nerve Injury in Implant Dentistry: Diagnosis, Causes, Prevention, and Management. J Oral Implantol. 2010; 36 (5): 401-407.

9. Wook-Jae Y, Su-Gwan K, Mi-Ae J, Ji-Su O, Jae-Seek Y: Prognosis and evaluation of tooth damage caused by implant fixtures. J Korean Assoc Oral Maxillofac Surg. 2013; 39 (3): 144-147.

10. DIVINYI T: Orális implantológia. Semmelweis Kiadó, Budapest 2007.

11. Kahraman S, Bal BT, Asar NV, Turkyilmaz I, Tözüm TF: Clinical study on the insertion torque and wireless resonance frequency analysis in the assessment of torque capacity and stability of selftapping dental implants. J Oral Rehabil. 2009; 36 (10): 755-761. 
12. Javed F, Ahmed HB, Crespi R, Romanos Ge: Role of primary stability for successful osseointegration of dental implants: Factors of influence and evaluation. Interv Med Appl Sci. 2013; 5 (4): 162-167.

13. Scharf DR, TARnow DP: The Swedish system of osseointegrated implants: problems and complications encountered during a 4-year trial period. J Periodontol. 1993; 64 (10): 954-956.

14. Mombelli A, van Oosten M A, Schurch E Jr, Land N P: The microbiota associated with successful or failing osseointegrated titanium implants. Oral Microbiol Immunol. 1987. 2, 2 (4): 145-151.

15. KLINGE B, Meyle J: Peri-implant tissue destruction. The Third EAO Consensus Conference 2012. Clin Oral Implants Res. 2012; 6: 108-110.

16. Heitz-Mayfield, LJ: Peri-implant diseases: diagnosis and risk indicators. J Clin Periodontol. 2008; 292-304.

17. Heitz-Mayfield LJ, Needleman I, Salvi GE: Consensus Statements and Clinical Recommendations for Prevention and Management of Biologic and Technical Implant Complications. Int J Oral Maxillofac Implants. 2014; 29: 346-350.

18. SCHWARZ, MS: Mechanical complications of dental implants. Clin Oral Implants Res. 2000; 1: 156-158.

19. YERIT KC ET AL: Implant survival in mandibles of irradiated oral cancer patients. Clin Oral Implants Res. 2006; 17 (3): 337-344.

20. Harrison JS, Strateman HS, Redding SW: Dental implants for patients who have had radiation treatment for head and neck cancer. Special Care in Dentistry. 2003; 23 (6): 223-229.

21. Szigethy E et al: Epidemiology of the metabolic syndrome in Hungary. Public Health. 2012; 126 (2): 143-149.

22. SzéLES G ET AL: Establishment and preliminary evaluation of the General Practitioners' Morbidity Sentinel Stations Program in Hungary. Prevalence of hypertension, diabetes mellitus and liver cirrhosis. Orv Hetil. 2003; 3; 144 (31): 1521-1529.
23. TомғA A: A daganatos betegségek előfordulása, a hazai és a nemzetközi helyzet ismertetése. Magy Tud. 2011; 11: 13331344.

24. Madléna M, Hermann $P$, Jáhn M, Fejérdy P: Caries prevalence and tooth loss in Hungarian adult population: results of a national survey. Public Health. 2008; 8: 364.

25. FÁbIÁN T, FEJÉRdY P, SOMOgYı E: Evaluation of the dental status from he viewpoint of denture requirements in the adult population of Hungary. Fogorv Sz. 1998; 91, 383-389; 91, 383-389.

26. Brånemark R, Ohrnell lo, Skalak R, Carlsson L, Brånemark PI: Biomechanical characterization of osseointegration: an experimental in vivo investigation in the beagle dog. $J$ Orthop Res. 1998; 16 (1): 61-69.

27. Winter W, KLeIN D, KarL, M: Micromotion of Dental Implants: Basic Mechanical Considerations. J Med Eng. 2013.

28. Charalampakis G, Leonhardt A, Rabe P, Dahlen G: Clinical and microbiological characteristics of peri-implantitis cases: a retrospective multicentre study. Clin Oral Implants Res. 2012; 23 (9): 1045-1054.

29. Ericsson I, Persson LG, Berglundh T, Marinello CP, Lindhe L, KLINGE B: Different types of inflammatory reactions in peri-implant soft tissues. J Clin Periodontol. 1995; 22 (3): 255-261.

30. Zitzmann, NU, Walter, C És Berglundh, T: Ätiologie, Diagnostik und Therapie der Periimplantitis - eine Übersicht. Dtsch Zahnarztl Z. 2006; 61: 642-649.

31. Rams TE, Degener JE, van Winkelhoff AJ: Antibiotic resistance in human peri-implantitis microbiota. Clin Oral Implants Res. 2013; 25: 82-90.

32. Salonen MA, Oikarinen K, Virtanen K, Pernu H: Failures in the Osseointegration of Endosseous Implants. Int $J$ Oral Maxillofac Implants. 1993; 8 (1): 92-97.

\section{IVÁNYI D, KIVOVICS P}

\section{Examination of dental implants removal}

The aim of this research is to make a comparative interpretation of implant removals in the last four years in the Department of Community Dentistry. The applied data were obtained by $\mathrm{x}$-rays, medical charts and patient management program, called FOGÁSZ, found in the Department of Community Dentistry. Data were evaluated with Microsoft Excel software. The last four years, 30 patients' 58 implants were removed in the Department of Community Dentistry. The average age was $64,3( \pm 8,8)$ years and $96,7 \%$ of the patients were aged 50 or over. $53,7 \%$ of the concerned individuals' inserted implants were removed. $20,0 \%$ of the patients lost their implants within six months from surgery. The removed implants were possessed $5,8( \pm 4,3)$ for years on average. $36,7 \%$ of the patients had fixed prosthesis supported implant and teeth, this was the most common prosthesis type. The prevalence of peri-implantitis around removed implants was $77,6 \%$. Out of the partly edentulous patients, horizontal bone resorption was discernible in $50,0 \% .12,1 \%$ of the removals were recommended because of inflammation before osseointegration. It is recommended not to plan any prostheses anchored at the same time to tooth and implant. Fixed prostheses simultaneously anchored on both tooth and implant may cause implant loss, because biomechanical aspects of anchoring behave differently in the bone. Prevention of periimplantitis is a key factor in the success of implants, which can be achieved by proper oral hygiene. Periodontitis could also promote the development of peri-implantitis. Patients with periodontitis should be cured of inflammation before implantation. Important factor for osseointegration is the inflammation-free healing.

Keywords: Dental implants, Periimplantitis, Implant complication, Implant removal, Implant failure 